\title{
GMO LABELING IN FOOD PRODUCTS IN MONTEVIDEO, URUGUAY
}

\author{
Arleo M. ${ }^{1,3}$, Benavente $P^{2}$., Cardozo V. ${ }^{2}$, Katz A. ${ }^{2,}$ Vázquez S. ${ }^{2}$,Da Silva Tavares A. ${ }^{2}$, \\ Legnani M. ${ }^{2}$, Martínez Debat C. ${ }^{* 1,3}$ \\ ${ }^{1}$ Laboratorio de Trazabilidad Molecular Alimentaria, Sección Bioquímica, Facultad de Ciencias, \\ Universidad de la República. \\ 2. Servicio de Regulación Alimentaria-Laboratorio de Bromatología, Intendencia de Montevideo. \\ 3. Núcleo Interdisciplinario Colectivo TÁ, Espacio Interdisciplinario, Universidad de la República.
}

\section{Abstract}

Montevideo establishes the mandatory labeling of foods containing genetically modified material through the Departmental Decree No. 36.554, positioning Uruguay within the 65 countries that have incorporated this type of regulation.

The Food Regulation Service, in its role of sanitary police, and through its Laboratory of Bromatology, in agreement with the Food Molecular Traceability Laboratory (Faculty of Sciences, University of the Republic), carried out the analysis of 206 products made with ingredients derived from corn and/or soybean, during the 2015-2017 period, within the framework of compliance with the aforementioned Decree.

The strategy used consisted of the application of molecular techniques (Real Time PCR), for the detection of common sequences present in the transgenic events of soybean and corn, and the subsequent quantification of the content of GM material, in relation to an established labeling threshold of $1 \%$.

As a result of this study, it was found that $36.9 \%$ of the analyzed foods presented sequences derived from genetically modified plant organisms (GMOs); and in 95\% of the cases, its content exceeded the threshold established for its labeling.

This study, constitutes the first approach to the knowledge of different transgenic elements distribution in food commercialized in Montevideo.

These results provide valuable information to both the consumer, for decision making about the food to be consumed, and also for the official control organizations, which must enforce the regulations.

This type of work has demonstrated, once again, the importance of the interrelation between academy and state agencies, in the generation of knowledge and in the implementation of new analytical methodologies, as well as in the training of qualified human resources and in the compliance with current regulations.

Keywords: GMOs, labeling, food legislation, consumer information, molecular techniques 


\section{Introduction}

According to the World Health Organization (WHO), "genetic modified food" are those derived from organisms whose genetic material (DNA) has been modified in a way that does not occur naturally, for example, through the introduction of a gene from a different organism (WHO, 2015).

In order to preserve the right to choose the consumption of genetically modified foods, , more than 60 countries have enacted legal measures to regulate their labeling; however, the specific characteristics of these regulations differ considerably from one country to another (Abad R. et al, 2004; Hilbeck et al., 2015; Dizon et al., 2016). Certain countries require mandatory labeling of foods that contain, are, or are derived from Genetically Modified Organisms (GMOs) (European Commission, 2003a, European Commission 2003b) while others have chosen to promote voluntary labeling (Acosta et al., 2015; Bovay, et. al, 2016; Just Label It Campaign, 2017). Despite the differences in these provisions, there is a broad consensus that the general objective of labeling is to inform consumers (Kamle et al., 2013). Also, it is assumed that such labeling is not a substitute for risk assessment of genetically modified food safety, but it serves as an additional and complementary control, in the regulatory process (J. Žel et al., 2012).

Uruguay is the tenth country with the highest production of transgenic crops worldwide and the fourth in South America after Brazil, Argentina and Paraguay (ISAAA, 2017). Since its introduction in 2003, ten transgenic varieties of corn, and five of soy, with agronomic characteristics of insects resistance and/or herbicide tolerance have been authorized for cultivation and processing. Also, thirteen additional soy and/or maize stacked events, which show combined agronomic characteristics for insect (and/or abiotic stress) resistance and/or insecticide tolerance, are in evaluation stages (Table 1)(GNBio,2017). 
Table 1. Transgenic varieties approved for cultivation, consumption and processing in Uruguay (2003-2017) (Taken from GNbio, 2017; Biosafety Clearing-House, 2017)

\begin{tabular}{|c|c|c|c|c|c|c|}
\hline \multirow{2}{*}{ Species / Event } & \multirow{2}{*}{ Agronomic characteristics } & \multirow{2}{*}{ Status in Uruguay } & \multicolumn{4}{|c|}{ Molecular Marker } \\
\hline & & & $35 S$ & $t$-NOS & bar & FMV \\
\hline Glycine max GTS 40-3-2 & Glyphosate tolerance & Approved 2/10/1996 & YES & YES & NO & NO \\
\hline G. $\max \mathrm{A} 2704-12(\mathrm{LL})$ & Ammonium glufosinate tolerance & Approved 19/9/2012 & YES & NO & NO & NO \\
\hline G. max M0N89788XM0N87701 (RR2YBt) & Glyphosate tolerance / Resistance to lepidóptera & Approved 19/9/2012 & NO & NO & NO & YES \\
\hline G. $\max$ BPS-CV127-9 & Ammonium glufosinate tolerance & Approved 29/10/2014 & NO & NO & NO & NO \\
\hline G. $\max$ DAS44406-6 & $2,4 \mathrm{D}$ tolerance & In evaluation & NO & NO & NO & NO \\
\hline G. $\max$ MON89788XMON87708 & Glyphosate tolerance & In evaluation & NO & NO & NO & YES \\
\hline G. $\max \mathrm{FG72}$ & Glyphosate and HPPD inhibitor herbicides tolerance & In evaluation & NO & YES & NO & NO \\
\hline G. $\max$ FG72XA5547-127 & Glyphosate, ammonium glufosinate and HPPD inhibitor herbicides tolerance & In evaluation & YES & YES & NO & NO \\
\hline G. $\max \mathrm{HB} 4-(\mathrm{PAT})$ & Abiotic stress (drought) tolerance & In evaluation & NO & YES & NO & NO \\
\hline G. max DAS44406-6XDAS81419-2 & $2,4 \mathrm{D}$, glyphosate and ammonium glufosinate tolerance / Resistance to lepidoptera & In evaluation & NO & NO & NO & NO \\
\hline G. max MON89788XMON87701XMON87708XMON87751 & Dicamba and glyphosate tolerance / Resistance to lepidóptera & In evaluation & NO & NO & NO & YES \\
\hline Zea mays MON810 & Resistance to lepidóptera & Approved 20/06/2003, 21/06/2011 & YES & NO & NO & NO \\
\hline Z. mays BT11 & Resistance to lepidoptera / Ammonium glufosinate tolerance & Approved 05/05/2004, 21/06/2011 & YES & YES & NO & NO \\
\hline Z. mays GA21 & Glyphosate tolerance & Approved 21/6/2011 & NO & YES & NO & NO \\
\hline Z. mays NK603 & Glyphosate tolerance & Approved 21/6/2011 & YES & YES & NO & NO \\
\hline Z. mays M0N810XNK603 & Glyphosate tolerance / Resistance to lepidóptera & Approved 21/6/2011 & YES & YES & NO & NO \\
\hline Z. mays TC1507XNK603 & Resistance to lepidoptera / Glyphosate and ammonium glufosinate tolerance & Approved 19/9/2012 & YES & YES & NO & NO \\
\hline Z. mays BT11XMIR162XGA21 (*) & Resistance to lepidoptera / Glyphosate and ammonium glufosinate tolerance & Approved 21/9/2012 & YES & YES & NO & NO \\
\hline Z. mays M0N89034XTC1507XNK603 (*) & Glyphosate and ammonium glufosinate tolerance / Resistance to lepidoptera & Approved 21/9/2012 & YES & YES & NO & NO \\
\hline Z. mays M0N89034XM0N88017 & Glyphosate tolerance /Resistance to lepidoptera and coleóptera & In evaluation & YES & YES & NO & NO \\
\hline Z. mays BT11XMIR162XMIR604XGA21 & $\begin{array}{l}\text { Glyphosate and ammonium glufosinate tolerance / Resistance to lepidoptera and } \\
\text { coleóptera }\end{array}$ & In evaluation & YES & YES & NO & NO \\
\hline Z. mays MON89034XNK603XTC1507XDAS40278-9 & $2,4 \mathrm{D}$, glyphosate and ammonium glufosinate tolerance / Resistance to lepidoptera & In evaluation & YES & YES & NO & NO \\
\hline Z. mays MON810XTC1507XNK603 & Resistance to lepidoptera / Glyphosate and ammonium glufosinate tolerance & In evaluation & YES & YES & NO & NO \\
\hline Z. mays T25 & Ammonium glufosinate tolerance & In evaluation & YES & NO & NO & NO \\
\hline
\end{tabular}


Uruguay regulates the use of genetically modified (GM) plants and their parts through a National Decree enacted in 2008. It promotes actions aimed at the implementation of the voluntary labeling "GM" or "non-GM", applicable to those foods in which the presence of DNA or genetically modified proteins can be verified through final product analysis (Decree 353/2008, 2008). More recently, in 2015, Montevideo (the country`s capital where more than $50 \%$ of the Uruguayan population lives) decreed mandatory labeling of all foods containing genetically modified organisms in a percentage higher than a threshold of 1\%. (Decrees № 34.901, 2013; № 35.099, 2014; and Nㅜㄴ.554, 2018). While this requirement applies only in Montevideo, it has prompted other three (out of 19) Uruguayan Departments to approve similar Decrees, and also a Decree of national scope is under discussion in the Uruguayan Parliament (Anzalone P., 2016) Given that in Uruguay most of soybean and corn crops are transgenic (ISAAA, 2017) it is possible that food made from raw materials derived from these species, contain genetically modified material, and that their presence is found in percentages that exceed the $1 \%$ threshold set in the regulation. In this context of GMOs regulation in Uruguay, it is essential to have analytical tools that guarantee compliance with the current Decrees.

Numerous methods have been described to detect GMO-derived material in food, feed and seeds (Fernandez, S., et al, 2005; Žel, J. et al., 2008; Querci, M. et al., 2010; Van den Eede et al., 2011; European Network of GMO laboratories (ENGL) 2011; Bonfini et al, 2012; Fraiture, M. A. et al., 2015), however, the most used methodology for this purpose is based on the detection of transgenic DNA using the Real Time PCR technique. (Van den Bulcke, M. et al., 2010; Barbau-Piednoir E et al., 2010; Cottenet, G. et al., 2013; Wu, Y., et al 2014; Huber, I. et al., 2013; Barbau-Piednoir E. et al., 2014; Bhoge, R. K. et al., 2016). Most studies in the available literature focuses on the design and development of these methods, but only a few study the GMO content in food found in the market (Cardarelli et.al, 2005; Viljoen, C. D., 2006; Prins, T. W.,et al, 2016; Elsanhoty et al., 2013).

The strategy for detecting and quantifying GMOs in food consists of several steps, as described in international standards ISO 24276: 2006, ISO 21569: 2005, ISO 21570: 2005, ISO 21571. First, DNA present in food is extracted; secondly, common DNA sequences sherd by most genetically modified plants are screened; in the case of a positive result, quantification of GMO content is performed.

The present study describes the use of molecular methods, based on Real Time PCR, for the detection, identification and quantification of genetically modified DNA sequences in foods manufactured from corn and soybean derived ingredients, sampled in Montevideo Department, between 2015 and 2017. This study was carried out within 
the framework of a collaboration and technological transfer Legal Agreement between the Official Service of Food Regulation of the Montevideo Municipality (Laboratory of Bromatology) and the Academy (Food Molecular Traceability Laboratory, Faculty of Sciences, University of the Republic).

\section{Materials and Methods}

\subsection{Sampling}

Between 2015 and 2017, the regulatory agency (Laboratory of Bromatology of the Municipality of Montevideo) conducted the sampling of different foods made with ingredients derived from corn or soybean (according to information declared by the manufacturer), from different commercial stores in the capital. These were chosen taking into account that in Uruguay only some transgenic lines of maize and soya species are authorized for consumption and processing (GNBio, 2017), so that only these two probably GM species should be present in commercialized foods.

Products containig both species were not included in this study, due to technical reasons. Products from different provenances, national and imported, were sampled, including those marketed by small producers and by multinational companies, provided that they did not present the label required by Decree 36.554 .

Product sampling was done according to the strategy established in the international standard ISO 21568 for the detection of GMOs in foodstuff (ISO 21568, 2005).

\subsection{DNA Purification}

Genomic DNA was extracted from 200 milligrams of homogenized material obtained from the processing of five units of each sample. Commercial kits, validated for use in complex food matrices, and following the manufacturer's specifications, were used. Foods with soy ingredients were processed using the SureFood $\Theta$ PREP Advanced kit (R-BIOPHARM), while foods made with corn were processed using the foodproof GMO extraction kit (BIOTECON Diagnostics). The obtained DNA was quantified by spectrophotometry using the NanoDrop 1000 micro-volume spectrophotometer (Thermo Scientific, USA).

\subsection{Detection of transgenic DNA sequences}

Real Time PCR technique was used to detect both the presence of plant DNA and four transgenicity DNA markers: the $35 S$ promoter sequence from Cauliflower Mosaic Virus (CaMV); the Agrobacterium tumefasciens terminator nos from nopaline-synthase 
enzyme ( $t$-NOS); the Scrophularia mosaic virus promoter (FMV); and the bar gene that codes phosphinothricin acetyltransferase enzyme (pat), from Streptomyces hygroscopicus. These markers are found in a wide variety of genetically modified corn and soybean lines released worldwide (ISAAA, 2017, Biosafety Clearing-House 2017), as well as in those authorized for consumption and processing in Uruguay. (GNbio, 2017) (Table 1).

DNA amplification was carried out using commercial kits: foodproof $\AA$ GMO Screening Kit (35S, t-NOS, bar, FMV) (BIOTECON Diagnostics) and SureFood® GMO SCREEN 4plex 35S/NOS/FMV/IAC (R-Biopharm), following manufacturers' specifications. All reactions were performed using the $A B I 7500$ PCR System thermocycler from Applied Biosystems.

2.4 Quantification of corn and soybean GM DNA.

For the quantification of DNA from GM maize, the commercial kit foodproof $\Theta$ GMO $35 S$ Maize Quantification Kit (BIOTECON Diagnostics) was used, while for the quantification of GM soybean, the commercial kit SureFood GMO Quant RR Soya (RBIOPHARM) was used. All amplifications were performed using the ABI 7500 PCR System thermocycler from Applied Biosystems.

\subsection{Statistical analysis}

To compare the results of the tests, Fisher's exact test was used, under the null hypothesis that there are no significant differences between the variables (Fisher, R.A, 1954). In all cases, a probability level of $p=0.05$ was used to accept or reject the hypothesis. All statistical analysis were performed using online GraphPad program (http://www.graphpad.com/quickcalcs/contingency1/)

\section{Results and discussion}

\subsection{Sampling of food coming from corn or soybean.}

A total of 206 food products $(n=206)$ made with ingredients derived from either corn ( $n$ $=128$ ) or soybean $(n=78)$, were sampled for this study.

Sampled products were classified into two categories according to the degree of food processing: natural or minimally processed foods (processed, $n=72$ ), and ultraprocessed products (ultra-processed, $n=134$ ), the latter group being understood as consisting of those foods that have gone through multiple processes of 
industrialization, and containing high amounts of additives, preservatives, stabilizers, and flavorings (Ministry of Public Health, 2016). (Table 2)

Tabla 2. Food analyzed in the 2015-2017 period. They were categorized based on product type (processed and ultra-processed foods), and according to the content of the vegetable species: corn or soybean, as stated in the market labeling.

\begin{tabular}{lccc}
\hline Food categories & Made with corn & Made with soybean & Total \\
\hline Processed & $\mathbf{n = 6 2}$ & $\mathbf{n = 1 0}$ & $\mathbf{n = 7 2}$ \\
Natural or canned grains & 39 & 6 & 45 \\
Flours & 17 & - & 17 \\
Starches & 6 & - & 6 \\
Vegetal proteins & - & 4 & 4 \\
Ultra-processed & $\mathbf{n = 6 6}$ & $\mathbf{n = 6 8}$ & $\mathbf{n = 1 3 4}$ \\
Cookies & 12 & 29 & 41 \\
CopSnacks & 17 & 10 & 27 \\
Deli Meats & - & 23 & 23 \\
Cereals & 22 & - & 22 \\
Sauces and juices & 7 & 6 & 13 \\
Dry pasta & 8 & - & 8 \\
\hline
\end{tabular}

\subsection{GM sequences detection}

The results of this study reveal that various foods made with ingredients derived from soybeans and corn, have DNA sequences from plant genetically modified organisms. These sequences were found in $36.9 \%$ of the foods analyzed in this study (76/206), being found in $29.7 \%$ of foods prepared with corn (38/128), and in $48.7 \%$ of products made with soybean (38/78), with a statistically significant difference between the two matrices $(p=0,0074)$ (Table 3).

On the other hand, the frequencies of presence of GM sequences in the processed and ultra-processed products were similar, without significant differences $(p=0.3637)$ (Table 3), unlike that reported in other related study. Gonzales and collaborators, found a lower GM maize presence in Mexican Artisan products, in comparison to Industrial Tortillas. This difference between the studies could be due to a difference in the sample universe, and/or also in the type and number of samples taken in both cases (Gonzales et al, 2017).

Among processed products derived from corn, starch showed a presence of $100 \%$ transgenes (6/6), vegetable protein $80 \%$ (8/10), and corn flour 76.5\% (13/17). The natural grains showed a presence of GM sequences of $7.7 \%$ (3/39). Among the ultra processed products, the deli meat products (chacinados) showed a frequency of transgene presence $60.9 \%$ (14/23), whereas snacks $48.1 \%(13 / 27)$. Dry pasta showed no presence of GM sequences (0/8). 
Table 3. Results of the analysis of transgenic sequences detection in foods made with ingredients derived from corn or soybeans. "GM": positive samples for the presence of transgenic sequences. "Non-GM": negative samples for the presence of transgenic sequences. "> 1\%": content of GM material greater than 1\%. "<1\%": content of GM material less than $1 \%$.

\begin{tabular}{lllllllllll}
\hline Food categories & $\mathbf{n}$ & $\mathbf{G M}$ & \multicolumn{3}{c}{ non-GM } & $>\mathbf{1 \%}$ & \multicolumn{2}{c}{$<$} \\
\hline Corn derived & $\mathbf{1 2 8}$ & $\mathbf{3 8}$ & $\mathbf{( 2 9 , 7 \% )}$ & $\mathbf{9 0}$ & $\mathbf{( 7 0 , 3 \% )}$ & $\mathbf{3 2}$ & $\mathbf{( 8 4 , 2 \% )}$ & $\mathbf{6}$ & $\mathbf{( 1 5 , 8 \% )}$ \\
Soybean derived & $\mathbf{7 8}$ & $\mathbf{3 8}$ & $\mathbf{( 4 8 , 7 \% )}$ & $\mathbf{4 0}$ & $\mathbf{( 5 1 , 3 \% )}$ & $\mathbf{3 4}$ & $\mathbf{( 8 9 , 5 \% )}$ & $\mathbf{4}$ & $\mathbf{( 1 0 , 5 \% )}$ \\
\hline Processed & $\mathbf{7 2}$ & $\mathbf{3 0}$ & $\mathbf{( 4 1 , 7 \% )}$ & $\mathbf{4 2}$ & $\mathbf{( 5 8 , 3 \% )}$ & $\mathbf{2 6}$ & $\mathbf{( 8 6 , 7 \% )}$ & $\mathbf{4}$ & $\mathbf{( 1 3 , 3 \% )}$ \\
Grains & 39 & 3 & $(7,7 \%)$ & 36 & $(92,3 \%)$ & 2 & $(66,7 \%)$ & 1 & $(33,3 \%)$ \\
Flours & 17 & 13 & $(76,5 \%)$ & 4 & $(23,5 \%)$ & 12 & $(92,3 \%)$ & 1 & $(7,7 \%)$ \\
Starches & 6 & 6 & $(100 \%)$ & 0 & $(0,0 \%)$ & 5 & $(83,3 \%)$ & 1 & $(16,7 \%)$ \\
Vegetal proteins & 10 & 8 & $(80,0 \%)$ & 2 & $(20,0 \%)$ & 7 & $(87,5 \%)$ & 1 & $(12,5 \%)$ \\
Ultra-processed & $\mathbf{1 3 4}$ & $\mathbf{4 6}$ & $\mathbf{( 3 4 , 3 \% )}$ & $\mathbf{8 8}$ & $\mathbf{( 6 5 , 7 \% )}$ & $\mathbf{4 0}$ & $\mathbf{( 8 6 , 9 \% )}$ & $\mathbf{6}$ & $(\mathbf{1 3 , 0 \% )}$ \\
Cookies & 41 & 13 & $(31,7 \%)$ & 28 & $(68,3 \%)$ & 13 & $(100 \%)$ & 0 & $(0,0 \%)$ \\
Snacks & 27 & 13 & $(48,1 \%)$ & 14 & $(51,9 \%)$ & 10 & $(76,9 \%)$ & 3 & $(23,1 \%)$ \\
Deli Meat (chacinados) & 23 & 14 & $(60,9 \%)$ & 9 & $(39,1 \%)$ & 12 & $(85,7 \%)$ & 2 & $(14,3 \%)$ \\
Cereals & 22 & 4 & $(18,2 \%)$ & 18 & $(81,8 \%)$ & 3 & $(75,0 \%)$ & 1 & $(25,0 \%)$ \\
Sauces and juices & 13 & 2 & $(15,4 \%)$ & 11 & $(84,6 \%)$ & 2 & $(100 \%)$ & 0 & $(0,0 \%)$ \\
Dry pasta & 8 & 0 & $(0,0 \%)$ & 8 & $(100 \%)$ & 0 & $(0,0 \%)$ & 0 & $(0,0 \%)$ \\
\hline TOTAL & $\mathbf{2 0 6}$ & $\mathbf{7 6}$ & $\mathbf{( 3 6 , 9 \% )}$ & $\mathbf{1 3 0}$ & $\mathbf{( 6 3 , 1 \% )}$ & $\mathbf{6 6}$ & $\mathbf{( 8 6 , 8 \% )}$ & $\mathbf{1 0}$ & $\mathbf{( 1 3 , 1 \% )}$ \\
\hline
\end{tabular}

It was also observed that the $35 \mathrm{~S}$ promoter sequence was present in all the samples that were positive for the detection test of GM material (76/76), while the t-NOS marker was found in $94.7 \%$ of them (72/76) (Table 4). Furthermore, the FMV promoter sequence was found in $51.3 \%$ of GM positive samples (39/76), showing a higher frequency in the products made with soybean when compared to those made with corn (65.8\% versus $36.8 \%$ in corn products). The sequence of the bar gene was not present in any of the analyzed products (Table 4).

Table 4. Transgenic sequences in processed and ultra-processed foods made with ingredients derived from corn or soybeans.

\begin{tabular}{llllllllll}
\hline Food categories & \multicolumn{1}{c}{ GM } & \multicolumn{2}{c}{ p35S } & \multicolumn{2}{l}{ t-NOS } & \multicolumn{2}{l}{ FMV } & \multicolumn{2}{l}{ bar } \\
\hline Corn & $\mathbf{3 8}$ & $\mathbf{3 8}$ & $\mathbf{( 1 0 0 \% )}$ & $\mathbf{3 7}$ & $\mathbf{( 9 7 . 4 \% )}$ & $\mathbf{1 4}$ & $\mathbf{( 3 6 . 8 \% )}$ & $\mathbf{0}$ & $\mathbf{( 0 . 0 \% )}$ \\
Soybean & $\mathbf{3 8}$ & $\mathbf{3 8}$ & $\mathbf{( 1 0 0 \% )}$ & $\mathbf{3 5}$ & $\mathbf{( 9 2 . 1 \% )}$ & $\mathbf{2 5}$ & $\mathbf{( 6 5 . 8 \% )}$ & NA & NA \\
\hline Processed & 30 & 30 & $(100 \%)$ & 29 & $(96.6 \%)$ & 11 & $(36.7 \%)$ & 0 & $(0.0 \%)$ \\
Ultra- processed & 46 & 46 & $(100 \%)$ & 43 & $(93.5 \%)$ & 28 & $60.9 \%)$ & 0 & $(0.0 \%$ \\
\hline TOTAL & $\mathbf{7 6}$ & $\mathbf{7 6}$ & $\mathbf{( 1 0 0 \% )}$ & $\mathbf{7 2}$ & $\mathbf{( 9 4 . 7 \% )}$ & $\mathbf{3 9}$ & $\mathbf{( 5 1 . 3 \% )}$ & $\mathbf{0}$ & $\mathbf{( 0 . 0 \% )}$ \\
\hline
\end{tabular}


Of all products tested, only two (2/76) showed a single transgenic element, this being the p35S. In no case was the unique presence of $t$-NOS or FMV sequences observed. At least two or three of these elements were present in $94.7 \%(72 / 76)$ of the samples . The sequences p35S and $t$-NOS were both present in $46.0 \%(35 / 76)$ of the GM positive samples, and the combination p35S, t-NOS and FMV was found in $48,7 \%$ (37/76) of them (not shown).

The high frequency of appearance of $35 S$ promoter and NOS terminator sequences in the analyzed samples, is in agreement with those described in the available bibliography, where it is described that both sequences are present in more than $80 \%$ of the transgenic events released and authorized for consumption, worldwide (ISAAA, 2017; Biosafety Clearing-House 2017). It should be noted that in Uruguay (and also in Southamerica), the transgenic varieties that are grown to a greater extent, (Bt11 and NK603 corn events, and GTS-40-3-2 soybean event) contain these two sequences in their genic construction (INASE, 2017). It was also observed that two of the analyzed products (a ground maize and a certain variety of sweet cookies) presented the $35 \mathrm{~S}$ promoter as the only transgenic sequence, which could be explained by the presence of some GM variety that does not contain the NOS terminator, such as the Mon810 corn event, also grown in our country and in the region (GNBio, 2017). Furthermore, the FMV promoter sequence was found in $51.3 \%$ of cases, always with $p 35 S$ and $t$ NOS sequences. This genetic element is usually found in a few soybean events, for example in the MON89788 variety (RR2Y, authorized in Uruguay for production of export seeds), in the variety MON89788XMIN87701 (RR2YBt, authorized for consumption), and also in the MON87705 variety, not yet authorized in our country. Also, this element is found in a single variety of corn, MON89034, which in Uruguay is authorized for consumption in the form of the MON89034XTC1507XNK603 stacked event. It should be noted that the sequence of the bar gene was not present in any of the analyzed products. This result is consistent with the fact that to date, in the world, only 7 corn and 2 soybean events have been authorized that contain this transgene, and they are grown in the United States, Japan and the Philippines. Only one of these events, the Bt176 maize variety iscommerciallyauthorized in Argentina (Biosafety Clearing-House 2017). The low frequency of the bar gene presence, and that of Bt176 event in mass consumption foods made from corn has already been reported in similar studies (Dinon et al, 2010; Gonzales Ortega et al, 2017). 


\subsection{GMO Quantification}

The quantification analysis of genetically modified material revealed that $86.8 \%(66 / 76)$ of the foods that were positive for detection of transgene sequences presented percentages greater than $1 \%, 84.2 \%$ of foods made from corn, and $89.5 \%$ of foods made from soy were found in this situation. Only $13.1 \%$ of the products that presented transgenic sequences (10/76), showed a content of GM material below this threshold. Among these, 4 were processed products and 6 were ultra-processed (Table 3).

The presence of GM material below the labeling threshold could be explained either by the use of different non-GM and GM ingredients that result in a final blend with low levels of GM material, or by unintentional contamination in the production chain. The latter could be the consequence oftransgene flow in crop production, contamination of the seeds during transportation, or during ingredients processing in the manufacturing plant (Aung et al, 2014).

It is important to note that although the legislation on the labeling of foods containing or derived from GMOs is in force in Montevideo since 2013, only a small fraction of foods made from corn and soybeans were found labeled, and these were not included in this study.

On the other hand, several products, national and imported, were observed with the legend "Non-transgenic certificate", "GMO free" or "Non GMO". This type of labeling is regulated in some countries such as the United States, where voluntary labeling is allowed for the presence and absence of GMOs (Albert, J. 2010; Just Label It, 2017). However, in Uruguay, unlike its capital Montevideo, there is still no regulation that contemplates or requires this distinction in the products. Among the foods labeled as "Non GMO", there is a soy sauce, two cereal mixes, a deli meats and a vegetable protein. Analysis of these products revealed the presence of transgenes in two of these samples.

\section{Conclusions}

This study evidenced the presence of sequences derived from genetically modified plant organisms in $36.9 \%$ of the foods analyzed, marketed in Montevideo. In addition, $95 \%$ of these foods showed a content exceeding the threshold percentage set for labeling GM material

These results allow to affirm that there is a greater presence of GM material in products that contain soybean compared to those that contain corn. Likewise, it was found that 
the contents of GM material between the processed and ultra-processed products were similar.

To date this study, constitutes the first approach to the knowledge of the distribution of different transgenic elements in certain products that are commercialized in Montevideo. This type of study highlights the need for policies regarding the labeling of foods derived from GMOs, in order to guarantee the consumer's right to know. Similarly, it provides objective information on the composition of foods, and enhances the importance of creating an effective regulatory system for monitoring and controlling this type of foods.

It would be interesting in the future to search for not yet authorized corn and soybean events in Uruguay, as well as analyzing new transgenic varieties of other plant species likely to be present in food. Although several uruguayan Departments have already chosen to incorporate the labeling of GM material in food, it would be possible to consider the formulation of a law with national scope.

\section{References}

Abad R., Concepción A., Franco A., Sánchez R., \& Rosales J. (2004). Organismos Modificados Genéticamente: Trazabilidad y Etiquetado. ULLED Biotecnología

Acosta, L., and Law Library of Congress. (2015). "Legal Report on the Restrictions on Genetically Modified Organisms: United States." Washington, DC: The Law Library of Congress; 2015. Available online at http://www.loc.gov/law/help/restrictions-on-gmos/usa.php. Accessed 25/04/2018

Albert, J. (2010). New technologies and food labelling: the controversy over labelling of foods derived from genetically modified crops. Innovations in food labelling, 153-167.

ISAAA. (2016). Global Status of Commercialized Biotech/GM Crops: 2016. ISAAA Brief No. 52. ISAAA: Ithaca, NY.

Anzalone P. (2016). Etiquetado de alimentos transgénicos: un derecho del consumidor. Revista Carne y Alimentos. Available online at https://cuadernosdeltaller.com/2015/08/06/etiquetado-dealimentos-transgenicos-un-derecho-del-consumidor/. Accessed 25/04/2018

Aung, M.M., \& Chang, Y.S., (2014). Traceability in a food supply chain: Safety and quality perspectives. Food control, 39, 172-184.

Barbau-Piednoir, E., Lievens, A., Mbongolo-Mbella, G., Roosens, N., Sneyers, M., Leunda-Casi A., (2010). SYBR $\circledast G$ reen $q P C R$ screening methods for the presence of "35S promoter" and "NOS terminator" elements in food and feed products. Eur Food Res Technol 230(3): 383-393

Barbau-Piednoir, E., Stragier, P., Roosens, N., Mazzara, M., Savini, C., Van den Eede, G., \& Van den Bulcke, M. (2014). Inter-laboratory testing of GMO detection by combinatory SYBR ${ }^{\circ}$ green PCR screening (CoSYPS). Food Analytical Methods, 7(8), 1719-1728. 
Bhoge, R. K., Chhabra, R., Singh, M., Sathiyabama, M., \& Randhawa, G. (2016). Multiplex realtime PCR-based detection and quantification of genetically modified maize events employing SYBR® Green I and TaqMan® chemistries. Current Science (00113891), 110(8).

Biosafety Clearing-House (2017). Available online at https://bch.cbd.int/. Accessed 25/04/2018

Bonfini, L., Van den Bulcke, M. H., Mazzara, M., Ben, E., \& Patak, A., (2012). GMOMETHODS: The European Union database of reference methods for GMO analysis. Journal of AOAC International, 95(6), 1713-1719. Available online at http://gmo-crl.jrc.ec.europa.eu/gmomethods/ Accessed 25/04/2018

Bovay, J., \& Alston, J. M., (2016). GM Labeling Regulation by Plebiscite: Analysis of Voting on Proposition 37 in California. Journal of Agricultural and Resource Economics, 41(2), 161-188.

Cardarelli, P., Branquinho, M. R., Ferreira, R. T., da Cruz, F.P., \& Gemal, A.L. (2005). Detection of GMO in food products in Brazil: the INCQS experience. Food control, 16(10), 859-866.

Cottenet, G., Blancpain, C., Sonnard, V., \& Chuah, P. F. (2013). Development and validation of a multiplex real-time PCR method to simultaneously detect 47 targets for the identification of genetically modified organisms. Analytical and bioanalytical chemistry, 405(21), 6831-6844.

Decreto 353/008 (2008). "Normas relativas a Bioseguridad de vegetales y sus partes genéticamente modificadas”. Diario Oficial № 27.534 - Julio 28 de 2008.

Decreto Municipal №36.554 (2018) Junta Departamental de Montevideo. Resolución № 5825/13. Intendencia de Montevideo, Uruguay. Resolución N722/18 Available online at http://www.montevideo.gub.uy/aplicacion/resolucion?parametro=722-18\&alto=8100. Accessed $2 / 5 / 2018$

Decreto Municipal № 34.901 (2013). Alimentos que contienen organismos genéticamente modificados. Junta Departamental de Montevideo. Resolución № 5825/13. Intendencia de Montevideo, Uruguay. Available online at http://www.juntamvd.gub.uy/es.php/archivos.php/decretos/8992-34901.htm. Accessed $25 / 04 / 2018$

Decreto Municipal № 35.099 (2014). Alimentos que contienen organismos genéticamente modificados. Junta Departamental de Montevideo. Resolución N²416/14 Intendencia de Montevideo, Uruguay. Available online at http://imnube.montevideo.gub.uy/share/s/fIXSUmSQQ2iJv49Hpah5nA. Accessed 25/04/2018

Dinon, A. Z., Bosco, K. T., \& Arisi, A. C. M. (2010). Monitoring of Bt11 and Bt176 genetically modified maize in food sold commercially in Brazil from 2005 to 2007. Journal of the Science of Food and Agriculture, 90(9), 1566-1569.

Dizon, F., Costa, S., Rock, C., Harris, A., Husk, C., \& Mei, J. (2016). Genetically modified (GM) foods and ethical eating. Journal of food Science, 81(2).

Elsanhoty, R. M., Al-Turki, A. I., \& Ramadan, M. F. (2013). Prevalence of genetically modified rice, maize, and soy in Saudi food products. Applied biochemistry and biotechnology, 171(4), 883-899. 
European Commission (2003). No 1830/2003 of the European Parliament and of the Council of 22 September 2003 concerning the traceability and labelling of genetically modified organisms and the traceability of food and feed products produced from genetically modified organisms and amending Directive 2001/18/EC. Official Journal, 50, 268.

European Commission (2005b) Definition of minimum performance requirements for analytical methods of GMO testing. Guidance documents on the website of the Community Reference Laboratory. 2005. 29-10-2007. Available online at the CRLGMFF website http://gmo-crl.jrc.it/. Accessed 25/04/2018

European Network of GMO laboratories (ENGL) (2011). Verification of analytical methods for GMO testing when implementing interlaboratory validated methods. EUR - Scientific and Technical Research series - ISSN 1831-9424, 23 pp.

Fernandez, S., Charles-Delobel, C., Geldreich, A., Berthier, G., Boyer, F., Collonnier, C., \& Romaniuk, M. (2005). Quantification of the $35 \mathrm{~S}$ promoter in DNA extracts from genetically modified organisms using real-time polymerase chain reaction and specificity assessment on various genetically modified organisms, part I: operating procedure. Journal of $A O A C$ International, 88(2), 547-557.

Fisher, R.A. (1954). Statistical Methods for Research Workers. Oliver and Boyd. ISBN 0-05002170-2.

Fraiture, M. A., Herman, P., Taverniers, I., De Loose, M., Deforce, D., \& Roosens, N. H. (2015). Current and new approaches in GMO detection: challenges and solutions. BioMed research international, 2015.

Gabinete Nacional de Bioseguridad (GNBio), Ministrerio de Ganadería, Agricultura y Pesca. Available online at http://www.mgap.gub.uy/unidad-organizativa/direccion-general-de-controlde-la-inocuidad-alimentario/bioseguridad/GNBio. Acceessed 25/04/2018

González-Ortega, E., Piñeyro-Nelson, A., Gómez-Hernández, E., Monterrubio-Vázquez, E., Arleo, M., Dávila-Velderrain, J., \& Álvarez-Buylla, R. E. (2017). Pervasive presence of transgenes and glyphosate in maize-derived food in Mexico. Agroecology and Sustainable Food Systems, (just-accepted).

Hilbeck, A., Binimelis, R., Defarge, N., Steinbrecher, R., Székács, A., Wickson, F. \& Novotny, E. (2015). No scientific consensus on GMO safety. Environmental Sciences Europe, 27(1), 4.

Huber, I., Block, A., Sebah, D., Debode, F., Morisset, D., Grohmann, L., \& Busch, U. (2013). Development and validation of duplex, triplex, and pentaplex real-time PCR screening assays for the detection of genetically modified organisms in food and feed. Journal of Agricultural and food chemistry, 61(43), 10293-10301.

Instituto Nacional de Semillas (INASE) (2017) Available online at the http://www.inase.org.uy/. Accessed 25/04/2018

ISO 21568 (2005). Foodstuffs - Methods of analysis for the detection of genetically modified organisms and derived products - Sampling.

ISO 21569 (2005). Foodstuffs - Methods of analysis for the detection of genetically modified organisms and derived products - Qualitative nucleic acid based methods 
ISO 21570 (2005). Foodstuffs - Methods of analysis for the detection of genetically modified organisms and derived products - Quantitative nucleic acid based methods

ISO 24276 (2006). Foodstuffs - Methods for the detection of genetically modified organisms and derived products - General requirements and definitions

Just Label It Campaign (2017). Labeling around the World. Available online at http://www.justlabelit.org/right-to-know-center/labeling-around-the-world/. Accessed 25/04/2018

Kamle, S., \& Ali, S. (2013). Genetically modified crops: detection strategies and biosafety issues. Gene, 522(2), 123-132.

Ministry of Public Health. (2016). Healthy Eating Guide. Available online at http://www.msp.gub.uy/sites/default/files/archivos adjuntos/MS guia web.pdf. Accessed $25 / 04 / 2018$

Prins, T. W., Scholtens, I. M., Bak, A. W., Van Dijk, J. P., Voorhuijzen, M. M., Laurensse, E. J., \& Kok, E. J. (2016). A case study to determine the geographical origin of unknown GM papaya in routine food sample analysis, followed by identification of papaya events 16-0-1 and 18-24. Food chemistry, 213, 536-544.

Querci, M., Van den Bulcke, M., Žel, J., Van den Eede, G., \& Broll, H. (2010). New approaches in GMO detection. Analytical and Bioanalytical Chemistry, 396(6), 1991-2002.

Viljoen, C. D., Dajee, B. K., \& Botha, G. M. (2006). Detection of GMO in food products in South Africa: Implications of GMO labelling. African journal of biotechnology, 5(2), 73-82.

Van den Bulcke, M., Lievens, A., Barbau-Piednoir, E., MbongoloMbella, G., Roosens, N., Sneyers, M., \& Casi, A. L. (2010). A theoretical introduction to "Combinatory SYBRß Green qPCR Screening", a matrix-based approach for the detection of materials derived from genetically modified plants. Analytical and bioanalytical chemistry, 396(6), 2113-2123.

Van den Eede, G., Bonfini, L., Cengia, L., lannini, C., Kluga, L., \& Mazzara, M. (2011). Compendium of reference methods for GMO analyses. Publications Office of the European Union, Luxembourg, Luxembourg. Available online at http://publications. jrc. ec. europa. eu/repository/handle/111111111/15068. Accessed 25/04/2018

World Health Organization. (2015). Frequently asked questions on genetically modified foods. Available online at http://www.who.int/foodsafety/areas work/food-technology/faq-geneticallymodified-food/en/. Accessed 25/04/2018

Wu, Y., Wang, Y., Li, J., Li, W., Zhang, L., Li, Y., \& Wu, G. (2014). Development of a general method for detection and quantification of the P35S promoter based on assessment of existing methods. Scientific reports, 4, 7358.

Žel, J., Mazzara, M., Savini, C., Cordeil, S., Camloh, M., Štebih, D.,\& Van den Eede, G. (2008). Method validation and quality management in the flexible scope of accreditation: an example of laboratories testing for genetically modified organisms. Food Analytical Methods, 1(2), 61-72.

Žel, J., Milavec, M., Morisset, D., Plan, D., Van den Eede, G., \& Gruden, K. (2012). How to reliably test for GMOs. In How to Reliably Test for GMOs (pp. 1-95). Springer US. 


\section{Supplementary Material}

Table I. Food made from soybeans or corn, domestic and imported. Specific brands are omitted, and local typical names are shown in italics. Results of detection of: p35: CaMV 355 promoter; t-NOS: Nos terminator; FMV: Scrophularia mosaic virus promoter; bar: gene that codes phosphinothricin acetyltransferase enzyme from Streptomyces hygroscopicus. NA: Not assayed. NL: No GMO labeling

\begin{tabular}{|c|c|c|c|c|c|c|c|c|c|c|c|}
\hline Muestra & Product type (in label) & Category & Species & $\begin{array}{c}\text { Country of } \\
\text { origin }\end{array}$ & $\begin{array}{c}\mathrm{GM} \\
\text { Screening }\end{array}$ & p35s & $\mathrm{t}-N O S$ & $F M V$ & bar & Quantification & Labeling \\
\hline 1 & Polenta corn flour & Processed & Corn & ARGENTINA & + & + & - & - & - & $>1 \%$ & $\mathrm{NL}$ \\
\hline 2 & Polenta corn flour & Processed & Corn & URUGUAY & + & + & + & - & - & $>1 \%$ & NL \\
\hline 3 & Polenta corn flour & Processed & Corn & URUGUAY & + & + & + & - & - & $>1 \%$ & NL \\
\hline 4 & Polenta corn flour & Processed & Corn & URUGUAY & + & + & + & - & - & $>1 \%$ & NL \\
\hline 5 & Polenta corn flour & Processed & Corn & URUGUAY & + & + & + & - & - & $>1 \%$ & NL \\
\hline 6 & Polenta corn flour & Processed & Corn & URUGUAY & + & + & + & - & - & $>1 \%$ & NL \\
\hline 7 & Polenta corn flour & Processed & Corn & URUGUAY & + & + & + & - & - & $>1 \%$ & NL \\
\hline 8 & Polenta corn flour & Processed & Corn & URUGUAY & + & + & + & - & - & $>1 \%$ & NL \\
\hline 9 & Polenta corn flour & Processed & Corn & URUGUAY & + & + & + & - & - & $>1 \%$ & NL \\
\hline 10 & Polenta corn flour & Processed & Corn & URUGUAY & + & + & + & - & - & $>1 \%$ & NL \\
\hline 11 & Instant biological polenta & Processed & Corn & ITALIA & - & - & - & - & - & NA & NL \\
\hline 12 & Precooked corn flour for polenta & Processed & Corn & ARGENTINA & + & + & + & + & - & $<1 \%$ & NL \\
\hline 13 & Corn flour to prepare polenta & Processed & Corn & URUGUAY & - & - & - & - & - & NA & NL \\
\hline 14 & Corn flour to prepare polenta & Processed & Corn & ITALIA & - & - & - & - & - & NA & NL \\
\hline 15 & Precooked corn flour with cheese & Processed & Corn & ITALIA & - & - & - & - & - & NA & NL \\
\hline 16 & Corn flour & Processed & Corn & URUGUAY & + & + & + & + & - & $>1 \%$ & NL \\
\hline 17 & Corn flour to prepare polenta & Processed & Corn & URUGUAY & + & + & + & - & - & $>1 \%$ & NL \\
\hline 19 & Cornstarch & Processed & Corn & BRASIL & + & + & + & - & - & $>1 \%$ & NL \\
\hline 20 & Cornstarch & Processed & Corn & URUGUAY & + & + & + & - & - & $>1 \%$ & NL \\
\hline 21 & Gluten-free Cornstarch & Processed & Corn & ARGENTINA & + & + & + & + & - & $>1 \%$ & NL \\
\hline 22 & Cornstarch & Processed & Corn & URUGUAY & + & + & + & + & - & $>1 \%$ & NL \\
\hline 23 & Wheat semolina & Processed & Corn & URUGUAY & + & + & + & - & - & $<1 \%$ & NL \\
\hline 24 & Yellow shelled corn & Processed & Corn & BRASIL & - & - & - & - & - & NA & $\mathrm{NL}$ \\
\hline 25 & Natural grain corn & Processed & Corn & BRASIL & - & - & - & - & - & NA & NL \\
\hline 26 & Sweet corn grain without added salt & Processed & Corn & EEUU & - & - & - & - & - & NA & NL \\
\hline 27 & Whole yellow corn kernels & Processed & Corn & ARGENTINA & - & - & - & - & - & NA & NL \\
\hline 28 & Whole yellow corn kernels & Processed & Corn & TAILANDIA & - & - & - & - & - & NA & NL \\
\hline
\end{tabular}


Trod corn to make porridge

Corn pisingallo to make popcorn

Caramelized Popcorn

Sweet popcorn

Pisingallo corn

Pisingallo corn

Scarlet mazamorra

Mixture to prepare popcorn

$$
\text { Popcorn Corn }
$$

Corn gluten-free pasta

Corn gluten-free pasta

Corn gluten-free pasta

Corn gluten-free pasta

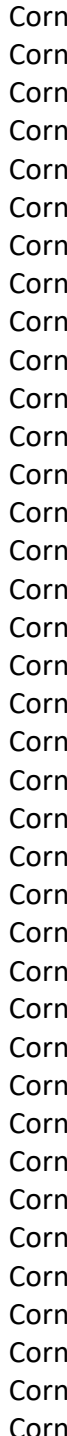

FRANCIA

BRASIL

BRASI

FRANCIA

ARGENTINA

BRASIL

URUGUAY

FRANCIA

CHINA

EEUU

ARGENTINA

BRASIL

BRASIL

BRASIL

BRASIL

TAILANDIA

BRASIL

BRASIL

BRASIL

BRASIL

BRASIL

BRASIL

ARGENTINA

ARGENTINA

URUGUAY

ARGENTINA

URUGUAY

URUGUAY

URUGUAY

ARGENTINA

ARGENTINA

BRASIL

BRASIL

RUMANIA

RUMANIA

AUSTRALIA RUMANIA
$\mathrm{NL}$

$\mathrm{NL}$

NL

NL

NL

NL

NL

$\mathrm{NL}$

NL

NL

NL

NL

NL

NL

$\mathrm{NL}$

NL

NL

$\mathrm{NL}$

NL

NL

NL

NL

$\mathrm{NL}$

NL

$\mathrm{NL}$

NL

$\mathrm{NL}$

$\mathrm{NL}$

$\mathrm{NL}$ 
White and yellow corn paste, and rice Dry pasta Italian spaghetti type

Dry pasta with garlic and parsley flavor

Dry pasta with vegetables

Nutricereal with honey and oats

Granola assortment of seeds with honey Cerealss

Cornflakes

Cornflakes

Cornflakes

Alimento estrusado

Alimento a base de cerereales

Sweetened cornflakes

Sweetened cornflakes Cornflakes

Cornflakes

Natural cornflakes

Dietetic cereals

Granola with nuts

Food based on corn flour

Sweetened cornflakes

Dietetic food with added vitamins

Cereals and dehydrated fruits mix Cornflakes$$
\text { Cornflakes }
$$

Food based on cereals, honey, nuts Tortillas wraps

Corn-based snack

Corn-based snack with cheese flavor

Corn-based snack with cheese flavor Tortillas

Baked corn toas

Salted Corn Fried Snack Product

Gluten free corn toast

Sticks with ham flavor

Corn flour sticks with cheese flavor

Corn Product corn based

Tacos dough

$\begin{array}{ccc}\text { Ultra-Processed } & \text { Corn } & \text { ITALIA } \\ \text { Ultra-Processed } & \text { Corn } & \text { AUSTRALIA } \\ \text { Ultra-Processed } & \text { Corn } & \text { ITALIA } \\ \text { Ultra-Processed } & \text { Corn } & \text { AUSTRALIA } \\ \text { Processed } & \text { Corn } & \text { URUGUAY } \\ \text { Processed } & \text { Corn } & \text { URUGUAY } \\ \text { Ultra-Processed } & \text { Corn } & \text { URUGUAY } \\ \text { Ultra-Processed } & \text { Corn } & \text { ARGENTINA } \\ \text { Ultra-Processed } & \text { Corn } & \text { ARGENTINA } \\ \text { Ultra-Processed } & \text { Corn } & \text { ARGENTINA } \\ \text { Ultra-Processed } & \text { Corn } & \text { ARGENTINA } \\ \text { Ultra-Processed } & \text { Corn } & \text { BRASIL } \\ \text { Ultra-Processed } & \text { Corn } & \text { ARGENTINA } \\ \text { Ultra-Processed } & \text { Corn } & \text { EEUU } \\ \text { Ultra-Processed } & \text { Corn } & \text { EEUU } \\ \text { Ultra-Processed } & \text { Corn } & \text { ARGENTINA } \\ \text { Ultra-Processed } & \text { Corn } & \text { ARGENTINA } \\ \text { Ultra-Processed } & \text { Corn } & \text { CHILE } \\ \text { Processed } & \text { Corn } & \text { URUGUAY } \\ \text { Processed } & \text { Corn } & \text { ARGENTINA } \\ \text { Ultra-Processed } & \text { Corn } & \text { BRASIL } \\ \text { Ultra-Processed } & \text { Corn } & \text { BRASIL } \\ \text { Processed } & \text { Corn } & \text { ALEMANIA } \\ \text { Ultra-Processed } & \text { Corn } & \text { BRASIL } \\ \text { Ultra-Processed } & \text { Corn } & \text { FRANCIA } \\ \text { Processed } & \text { Corn } & \text { URUGUAY } \\ \text { Ultra-Processed } & \text { Corn } & \text { ESPAÑA } \\ \text { Ultra-Processed } & \text { Corn } & \text { MEXICO } \\ \text { Ultra-Processed } & \text { Corn } & \text { EEUU } \\ \text { Ultra-Processed } & \text { Corn } & \text { BÉLGICA } \\ \text { Ultra-Processed } & \text { Corn } & \text { ALEMANIA } \\ \text { Ultra-Processed } & \text { Corn } & \text { MEXICO } \\ \text { Ultra-Processed } & \text { Corn } & \text { BÉLGICA } \\ \text { Ultra-Processed } & \text { Corn } & \text { AUSTRALIA } \\ \text { Ultra-Processed } & \text { Corn } & \text { ARGENTINA } \\ \text { Ultra-Processed } & \text { Corn } & \text { EEUU } \\ \text { Ultra-Processed } & \text { Corn } & \text { ARGENTINA } \\ \text { Ultra-Processed } & \text { Corn } & \text { EEUU } \\ & & \end{array}$

NA
NA
NA
NA
$>1 \%$
NA
$>1 \%$
NA
NA
NA
NA
$>1 \%$
NA
NA
NA
NA
NA
NA
NA
$<1 \%$
NA
NA
NA
NA
NA
NA
NA
NA
$>1 \%$
NA
NA
$<1 \%$
NA
NA
NA
$>1 \%$
$>1 \%$
$<1 \%$


Roast beef flavor snack Vegatable mix flavor snack Cheese flavor corn butty Quinoa based snack product Corn tortilla

Cornmeal and cocoa cookies with chocolate Powder to prepare vanilla flavor muffins Powder to prepare sponge cake Sweet cookies with bran Lemon flavor pudding Chocolate and vanilla flavor pudding Vanilla flavor dessert powder Vanilla flavor dessert powder Sweet cookie María type without gluten Vanilla flavor dessert powder

Corn cookies

Corn cookies

White sauce

Mayonnaise light Tartar sauce

Corn and butter instant cream soup Ketchup sauce reduced in caloric value Ketchup sauce

Mustard-based seasoning

Cooked peeled chorizo, choripan

Milanese of chard, spinach and soy Hotdogs light

Chorizo flavored burger Beef burger Extra chorizo

Chicken nuggets with cheese

Frankfurter type sausage

Frankfurter type sausage Longaniza

Beef burger

Pasteurized chorizo
Ultra-Processed

Ultra-Processed

Ultra-Processed

Ultra-Processed

Ultra-Processed

Ultra-Processed

Ultra-Processed

Ultra-Processed

Ultra-Processed

Ultra-Processed

Ultra-Processed

Ultra-Processed

Ultra-Processed

Ultra-Processed

Ultra-Processed

Ultra-Processed

Ultra-Processed

Ultra-Processed

Ultra-Processed

Ultra-Processed

Ultra-Processed

Ultra-Processed

Ultra-Processed

Ultra-Processed

Ultra-Processed

Ultra-Processed

Ultra-Processed

Ultra-Processed

Ultra-Processed

Ultra-Processed

Ultra-Processed

Ultra-Processed

Ultra-Processed

Ultra-Processed

Ultra-Processed

Ultra-Processed

Ultra-Processed
Corn

Corn

Corn

Corn URUGUAY

Corn ESPAÑA

Corn URUGUAY

Corn URUGUAY

Corn ARGENTINA

Corn ARGENTINA

Corn URUGUAY

Corn URUGUAY

Corn URUGUAY

Corn ITALIA

Corn ESPAÑA

Corn URUGUAY

Corn URUGUAY

Corn URUGUAY

Corn ARGENTINA

Corn REINO UNIDO

Corn ARGENTINA

Corn BRASIL

Corn URUGUAY

Corn URUGUAY

Soybean URUGUAY

Soybean

Soybean

Soybean

Soybean

Soybean

Soybean

Soybean

Soybean

Soybean

Soybean

Soybean

ARGENTINA

URUGUAY

URUGUAY

URUGUAY

URUGUAY

BRASIL

URUGUAY

URUGUAY

URUGUAY

URUGUAY

URUGUAY
$>1 \%$

NA

NA

$>1 \%$

NA

$>1 \%$

NA

NA

NA

NA

NA

NA

NA

$>1 \%$

$>1 \%$
$>1 \%$

NA

NA

NA

NA

NA

$\mathrm{NL}$

$\mathrm{NL}$

$\mathrm{NL}$

NL

$\mathrm{NL}$

$\mathrm{NL}$

NL

$\mathrm{NL}$

NL

NL

NL

$\mathrm{NL}$

$\mathrm{NL}$

$\mathrm{NL}$

$\mathrm{NL}$

$\mathrm{NL}$

"Soybean

certificada no

transgénica"

$>1 \%$

$>1 \%$

NA
$>1 \%$

NA

$>1 \%$

$>1 \%$

$>1 \%$

$>1 \%$ 


141
142
143
144
145
146
147
148
149
150
151
152
153
154
155
156
157
158
159
160
161
162
163
164
165
166
167
168
169
170
171
172
173
174
175
176
177
178

Frankfurter type sausage
Frankfurter type sausage
Frozen meat burger
Frankfurter type sausage
Extra chorizo with cheese and olives
Low sodium super frozen burgers
Frozen burgers

Ultra-Processed Soybean URUGUAY

Soybean URUGUAY

Ultra-Processed Soybean URUGUAY

Ultra-Processed Soybean URUGUAY

Ultra-Processed Soybean URUGUAY

Seasoned and breaded ground chicken meat

Ultra-Processed

Soybean

Liver pate

Ultra-Processed

Ultra-Processed

Meat pate

Pork paste

Soy milanese

Filet of soybean milanese type

Mixture to prepare soybean steaks

Filet of soybean milanese type

Soybean protein textured and granulated

Soybean protein granulated

$$
\text { Soy beans }
$$

Assortment of seeds with soy protein Soy sauce

Soy sauce

Original soy sauce

Vanilla flavor dessert powder

Sweet bread filled $\mathrm{w} /$ sweet milk (dulce de leche)

Vanilla flavor budin and chocolate chips

Premix for preparing rice bread

Sweet piles stuffed with quince jam

Sweet cookies with oats, apples, and cinnamon Sweet cookies

Waffles filled with hazelnut paste

$$
\begin{aligned}
& \text { Sweet cake } \\
& \text { Artisan wafers }
\end{aligned}
$$

Sweet cookies decorated with chips

Vanilla sponge cake with chocolate filling

$$
\text { Sugary biscuits }
$$

Sweet cookies filled with lemon flavor

Ultra-Processed

Ultra-Processed

Ultra-Processed

Ultra-Processed

Ultra-Processed

Processed

Processed

Processed

Processed

Processed

Processed

Ultra-Processed

Ultra-Processed

Ultra-Processed

Ultra-Processed

Soybean

Soybean

Soybean

Soybean

Soybean

Soybean

Soybean

Soybean

Soybean

Soybean

Soybean

Soybean

Soybean

Soybean

Soybean

Soybean

Soybean

Ultra-Processed Soybean

Ultra-Processed

Ultra-Processed

Soybean

Soybean

Ultra-Processed Soybean

Ultra-Processed

Ultra-Processed

Soybean

Soybean

Soybean

Ultra-Processed

Ultra-Processed

Ultra-Processed

Soybean

Soybean

Soybean

Ultra-Processed Soybean

Soybean

BRASIL

BRASIL

BRASIL

FRANCIA

URUGUAY

URUGUAY

ARGENTINA

ARGENTINA

URUGUAY

URUGUAY

URUGUAY

URUGUAY

EEUU

CHINA

EEUU

ARGENTINA

URUGUAY

ARGENTINA

URUGUAY

ARGENTINA

ARGENTINA

URUGUAY

GRECIA

BRASIL

URUGUAY

URUGUAY

POLONIA

ARGENTINA

ARGENTINA

$\mathrm{NL}$

NL

NL

$\mathrm{NL}$

$\mathrm{NL}$

$\mathrm{NL}$

NL

NL

NL

"No transgénico"

$\mathrm{NL}$

$\mathrm{NL}$

$\mathrm{NL}$

$\mathrm{NL}$

$\mathrm{NL}$

NL

$\mathrm{NL}$

$\mathrm{NL}$

$\mathrm{NL}$

$\mathrm{NL}$

$\mathrm{NL}$

$\mathrm{NL}$

NL

$\mathrm{NL}$

$\mathrm{NL}$

$\mathrm{NL}$

$\mathrm{NL}$

$\mathrm{NL}$

$\mathrm{NL}$

NL

$\mathrm{NL}$ 


\begin{tabular}{|c|c|c|c|c|c|c|c|c|c|c|c|}
\hline 179 & Cookies with Milk & Ultra-Processed & Soybean & URUGUAY & - & - & - & - & - & NA & $\mathrm{NL}$ \\
\hline 180 & Wafers with vanilla flavor filling & Ultra-Processed & Soybean & BRASIL & - & - & - & - & - & NA & $\mathrm{NL}$ \\
\hline 181 & Waffles with lemon flavor filling & Ultra-Processed & Soybean & GRECIA & - & - & - & - & - & NA & NL \\
\hline 182 & Galletitas dulces medialunitas & Ultra-Processed & Soybean & ARGENTINA & - & - & - & - & - & NA & $\mathrm{NL}$ \\
\hline 183 & Mini magdalena cupcakes & Ultra-Processed & Soybean & FRANCIA & - & - & - & - & - & NA & $\mathrm{NL}$ \\
\hline 184 & Sweet cookies with chocolate chips & Ultra-Processed & Soybean & ALEMANIA & - & - & - & - & - & NA & $\mathrm{NL}$ \\
\hline 185 & Cookies with almonds and chocolate chips & Ultra-Processed & Soybean & FRANCIA & - & - & - & - & - & NA & NL \\
\hline 186 & Sweet cookies decorated with chips & Ultra-Processed & Soybean & ARGENTINA & - & - & - & - & - & NA & NL \\
\hline 187 & Sweet cookies with chocolate chips & Ultra-Processed & Soybean & URUGUAY & - & - & - & - & - & NA & $\mathrm{NL}$ \\
\hline 188 & Sweet cookies with vanilla and chocolate flavor & Ultra-Processed & Soybean & URUGUAY & + & + & + & + & - & $>1 \%$ & NL \\
\hline 189 & Lemon flavor waffle & Ultra-Processed & Soybean & BRASIL & - & - & - & - & - & NA & $\mathrm{NL}$ \\
\hline 190 & American-style pancakes with dulce de leche & Ultra-Processed & Soybean & URUGUAY & - & - & - & - & - & NA & $\mathrm{NL}$ \\
\hline 191 & Sweet cookies with vanilla and chocolate flavor & Ultra-Processed & Soybean & URUGUAY & + & + & + & - & - & $>1 \%$ & $\mathrm{NL}$ \\
\hline 192 & Oatmeal sweet cookies with vanilla flavor & Ultra-Processed & Soybean & ARGENTINA & + & + & + & + & - & $>1 \%$ & $\mathrm{NL}$ \\
\hline 193 & Assorted cookies & Ultra-Processed & Soybean & URUGUAY & - & - & - & - & - & NA & NL \\
\hline 194 & Liquid soy food with fruit juice & Ultra-Processed & Soybean & ARGENTINA & - & - & - & - & - & NA & $\mathrm{NL}$ \\
\hline 195 & Soy dietary food strawberry flavor & Ultra-Processed & Soybean & BRASIL & - & - & - & - & - & NA & $\mathrm{NL}$ \\
\hline 196 & Liquid soy food sabor with vanilla flavor & Ultra-Processed & Soybean & ITALIA & + & + & - & + & - & $>1 \%$ & $\mathrm{NL}$ \\
\hline 197 & Whole-grain toast & Ultra-Processed & Soybean & BRASIL & - & - & - & - & - & NA & $\mathrm{NL}$ \\
\hline 198 & Multigrain toasts & Ultra-Processed & Soybean & BRASIL & + & + & - & + & - & $>1 \%$ & $\mathrm{NL}$ \\
\hline 199 & Crockers cookies with bran & Ultra-Processed & Soybean & ARGENTINA & + & + & + & - & - & $>1 \%$ & $\mathrm{NL}$ \\
\hline 200 & Biscuit stick artificial flavor milk & Ultra-Processed & Soybean & BRASIL & + & + & + & - & - & $<1 \%$ & NL \\
\hline 201 & Salty rice cakes & Ultra-Processed & Soybean & ARGENTINA & - & - & - & - & - & NA & $\mathrm{NL}$ \\
\hline 202 & Onion and parsley flavor cereal snacks & Ultra-Processed & Soybean & BRASIL & - & - & - & - & - & NA & $\mathrm{NL}$ \\
\hline 203 & Instant soup with meat flavor & Ultra-Processed & Soybean & EEUU & + & + & + & + & - & $>1 \%$ & NL \\
\hline 204 & Salty biscuit with bran & Ultra-Processed & Soybean & PARAGUAY & - & - & - & - & - & NA & $\mathrm{NL}$ \\
\hline 205 & Cracker cookies & Ultra-Processed & Soybean & ARGENTINA & - & - & - & - & - & NA & $\mathrm{NL}$ \\
\hline 206 & Rice crackers flavored with herbs & Ultra-Processed & Soybean & URUGUAY & + & + & + & - & - & $>1 \%$ & $\mathrm{NL}$ \\
\hline
\end{tabular}

Acknowledgments. The authors would like to acknowledge C.S.I.C. (Comisión Sectorial de Investigación Científica-UdelaR), Espacio InterdisciplinarioUdelaR, PEDECIBA, Biotechnology Master Program-UdelaR, and Intendencia de Montevideo for financial support of this work.

\section{Conflict of interest statement}

The authors declare that they have no conflict of interest. 